\title{
Red-Cell Distribution Width (RDW) dan Mean Platelet Volume (MPV) sebagai Biomarker Keparahan Pneumonia Anak
}

Wigit Kristianto, Retno Asih Setyoningrum, ${ }^{*}$ Agoes Boediono ${ }^{* *}$

Dokter Umum RSU Djatiroto Lumajang, "SMF Ilmu Kesehatan Anak Fakultas Kedokteran Universitas Airlangga/RSUD dr. Soetomo Surabaya, ${ }^{* *}$ SMF Ilmu Kesehatan Anak RSUD Nganjuk

Latar belakang. Pneumonia masih menjadi salah satu penyebab utama morbiditas dan mortalitas anak balita di seluruh dunia. Red-cell distribution width (RDW) dan mean platelet volume (MPV) adalah dua parameter dalam pemeriksaan darah lengkap yang sederhana, murah, dan tersedia hampir di seluruh rumah sakit di Indonesia. Penggunaannya sebagai biomarker keparahan pneumonia dapat menjadi salah satu upaya untuk menurunkan morbiditas dan mortalitas akibat pneumonia.

Tujuan. Menganalisis hubungan antara nilai RDW dan MPV dengan derajat keparahan pneumonia anak.

Metode. Penelitian cross-sectional dilaksanakan pada Juni-November 2017 di RSUD Nganjuk, melibatkan 30 anak berusia 2-59 bulan dengan pneumonia. Nilai RDW dan MPV dihubungkan dengan klasifikasi diagnosis, derajat keparahan yang diukur menggunakan skor RISC (respiratory index of severity in children) dan PRESS (pediatric respiratory severity score), dan hasil terapi pneumonia.

Hasil. Terdapat perbedaan bermakna pada nilai RDW antara subjek dengan pneumonia dan pneumonia berat $(\mathrm{t} 28=-1,721, \mathrm{p}=0,096)$. Nilai RDW antara kelompok dengan nilai PRESS rendah, sedang, dan tinggi juga berbeda bermakna $(F(2,27)=4,083, p=0,028)$. Nilai RDW berhubungan bermakna kuat dengan klasifikasi diagnosis pneumonia $(x(1)=0,530, p=0,004)$, dan berhubungan bermakna moderate dengan skor RISC $\left(r_{s}=0,369, p=0,023\right)$, serta skor PRESS $\left(r_{s}=0,318, p=0,043\right)$.

Kesimpulan. Nilai RDW berhubungan dengan klasifikasi diagnosis pneumonia, skor RISC dan skor PRESS. Sari Pediatri 2018;19(6): $335-41$

Kata kunci: pneumonia, biomarker, RDW, MPV, keparahan pneumonia

\section{Red-Cell Distribution Width (RDW) and Mean Platelet Volume (MPV) as Biomarkers of Childhood Pneumonia Severity}

Wigit Kristianto, Retno Asih Setyoningrum, Agoes Boediono

Background. Pneumonia is leading cause of morbidity and mortality of children under five around the world. RDW and MPV are simple and cheap parameters in complete blood examination that available in almost all hospitals in Indonesia. Its use as biomarkers of pneumonia severity is expected to decline pneumonia morbidity and mortality.

Objective. To analyze the association between RDW and MPV values with pneumonia severity in children under five.

Methods. A cross-sectional study was conducted in June-November 2017 at Nganjuk General Hospital involving 30 children aged 2-59 months with pneumonia. We analyzed the association of RDW and MPV values with a classification of pneumonia, the severity of pneumonia measured using RISC (respiratory index of severity in children) and PRESS (pediatric respiratory severity score) scores, and therapeutic results.

Result. There was a significant difference in RDW value between subjects with pneumonia and severe pneumonia ( $28=-1.721$, $\mathrm{p}=0.096)$. RDW value has significant difference in the subjects with low, medium, and high PRESS values $(\mathrm{F}(2,27)=4.083$, $\mathrm{p}=0.028)$. RDW value has strong significant association with the classification of pneumonia $(x(1)=0.530, p=0.004)$, moderate significant association with RISC score $\left(\mathrm{r}_{\mathrm{s}}=0.369, \mathrm{p}=0.023\right)$, and PRESS score $\left(\mathrm{r}_{\mathrm{s}}=0.318, \mathrm{p}=0.043\right)$.

Conclusion. RDW value was associated with classification of pneumonia, RISC score and PRESS score. Sari Pediatri 2018;19(6): 335-41

Keywords: pneumonia, biomarker, RDW, MPV, pneumonia severity

Alamat korespondensi: Dr. Retno Asih Setyoningrum, dr., Sp.A(K). Departemen Ilmu Kesehatan Anak Fakultas Kedokteran Universitas Airlangga/RSUD dr. Soetomo, Divisi Respirologi Anak, Gedung Kwari lantai 2. E-mail : ikafkunair@rsds.or.id 
Wigit Kristianto dkk: RDW dan MPV sebagai biomarker keparahan pneumonia anak

$\mathrm{P}$ numonia adalah penyakit infeksi yang menyebabkan keradangan pada parenkim paru. Penyakit ini masih menjadi salah satu penyebab utama morbiditas dan mortalitas anak usia balita di seluruh dunia. Pneumonia merupakan salah satu alasan utama perawatan rumah sakit pada anak di negara berkembang ${ }^{1}$. Morbiditas akibat pneumonia di Asia Tenggara diperkirakan berkisar antara 0,13-0,61 angka kesakitan/anak/ tahun dengan total angka kematian diperkirakan 336.700-534.200 kematian/tahun. ${ }^{1}$ Prevalensi pneumonia anak balita di Indonesia menurut data Riset Kesehatan Dasar (Riskesdas) 2013 adalah $1,6 \%$. Indonesia masih menjadi salah satu dari 15 negara yang berkontribusi pada $65 \%$ morbiditas dan $74 \%$ mortalitas yang disebabkan oleh pneumonia di seluruh dunia. ${ }^{1}$

Triase dan terapi yang terfokus, walaupun tanpa pemeriksaan penunjang yang canggih diperlukan untuk mencegah kemunculan kasus pneumonia dengan manifestasi klinis dan komplikasi yang berat. Beberapa biomarker yang sederhana, murah, dan tersedia secara luas dapat digunakan untuk menilai derajat keparahan pneumonia. Biomarker tersebut antara lain red-cell distribution width (RDW) dan mean platelet volume (MPV). Pemeriksaan RDW dan MPV relatif sering dilakukan karena menjadi salah satu parameter dalam pemeriksaan darah lengkap, tetapi nilai klinisnya jarang diperhatikan. Banyak penelitian telah menyimpulkan bahwa RDW memiliki hubungan yang kuat dengan biomarker inflamasi lain seperti laju endap darah $(\text { LED })^{2}$ dan $C$-reactive protein (CRP). ${ }^{2,3}$

Biomarker RDW dan MPV terbukti berhubungan dengan berbagai penyakit inflamasi, termasuk pneumonia. Penyakit gagal jantung ${ }^{4}$, infark miokard ${ }^{5}$, irritable bowel disease, ${ }^{6}$ hashimoto's tiroiditis, ${ }^{7}$ dan hepatosteatosis ${ }^{8}$ diketahui berhubungan dengan RDW. Hepatosteatosis, ${ }^{8}$ kista hidatid hepar, ${ }^{9}$ prostatitis kronis, ${ }^{10}$ dan diabetes mellitus tipe $2^{11}$ diketahui berhubungan dengan MPV. Biomarker RDW dan MPV juga telah terbukti sebagai prediktor prognosis penyakit pada pasien dewasa dengan community acquired pneumonia (CAP), ${ }^{12,13}$ tetapi penelitian pada pasien pneumonia anak masih terbatas.

Penelitian ini akan menganalisis hubungan antara nilai RDW dan MPV dengan derajat keparahan pneumonia pada anak balita. Biomarker RDW dan MPV adalah dua parameter dalam pemeriksaan darah lengkap yang sederhana, murah, dan tersedia hampir di seluruh rumah sakit di Indonesia. Penggunaan biomarker tersebut diharapkan dapat menjadi salah satu upaya untuk menurunkan angka kesakitan dan kematian akibat pneumonia.

\section{Metode}

Penelitian ini dilakukan dengan rancangan penelitian cross sectional. Data penelitian berasal dari pasien pneumonia berumur 2-59 bulan di ruang rawat inap anak RSUD Nganjuk mulai Juni-November 2017. Pemeriksaan darah lengkap dilakukan saat pertama kali pasien datang ke rumah sakit. Kriteria inklusi yang digunakan adalah balita laki-laki dan perempuan dengan diagnosis pneumonia yang telah dikonfirmasi oleh dokter penanggung jawab pasien dan mendapat informed consent dari orang tua. Kriteria eksklusi adalah pasien sedang menjalani imunoterapi, konsumsi steroid, mendapat transfusi darah dalam tiga bulan terakhir, atau data tidak lengkap.

Variabel yang dinilai, antara lain, nilai RDW, nilai MPV, klasifikasi diagnosis pneumonia, derajat keparahan pneumonia, dan hasil terapi pneumonia. Nilai RDW dengan satuan \% diukur menggunakan metode flow cytometry dengan nilai normal 11,5-14,5\%. ${ }^{12}$ Nilai MPV dengan satuan fL diukur menggunakan metode flow cytometry dengan nilai normal 7,0-11,0 fL. ${ }^{14}$ Klasifikasi diagnosis pneumonia dibagi menurut klasifikasi WHO 2014. ${ }^{15}$ Derajat keparahan pneumonia menggunakan sistem skor Respiratory Index of Severity in Children (RISC) ${ }^{16}$ dan Pediatric Respiratory Severity Score (PRESS) ${ }^{17}$. Hasil terapi dinilai menggunakan kriteria respon terapi menurut Kemenkes RI $2015^{18}$ dan outcome terapi yaitu pasien menjadi sembuh atau meninggal.

Data dianalisis menggunakan uji komparasi dan korelasi. Uji komparasi menggunakan uji t tidak berpasangan atau one way ANOVA jika data terdistribusi normal, atau menggunakan uji Kruskall Wallis atau Mann-Withney jika data tidak terdistribusi normal. Uji korelasi menggunakan uji korelasi Pearson jika data terdistribusi normal, atau menggunakan uji Spearman atau chi kuadrat jika data tidak terdistribusi normal. Perbedaan atau hubungan dikatakan bermakna jika $\mathrm{p}<0,05$. 


\section{Hasil}

Total 30 subjek pada penelitian ini didiagnosis pneumonia (6 subjek) atau pneumonia berat (24 subjek). Dua subjek dieksklusi karena data nilai RDW dan MPV pada laporan pemeriksaan darah lengkap tidak muncul. Analisis yang berhubungan dengan nilai MPV hanya menggunakan data dari 28 pasien, karena terdapat 2 subjek yang nilai MPV-nya tidak muncul. Karakteristik subjek dari penelitian ini tertera pada Tabel 1.

Tabel 2 menunjukkan perbedaan nilai rata-rata RDW dan MPV pada berbagai variabel independen pada penelitian ini. Terdapat perbedaan yang bermakna pada nilai RDW antara subjek dengan pneumonia dan pneumonia berat $(\mathrm{t} 28=-1,721, \mathrm{p}=0,096)$. Perbedaan bermakna lain didapatkan pada nilai rata-rata RDW antara kelompok dengan nilai PRESS rendah, sedang, dan tinggi $(\mathrm{F}(2,27)=4,083, \mathrm{p}=0,028)$. Uji post hoc tidak dapat dilakukan untuk mencari perbedaan pada kelompok mana yang bermakna pada variabel PRESS karena hanya terdapat satu subjek dengan skor PRESS rendah. Pada kelompok variabel independen lain tidak didapatkan perbedaan yang bermakna pada nilai RDW maupun MPV. Nilai RDW dan MPV kemudian diubah menjadi data kategorial menurut nilai normal yang telah disepakati untuk diuji kekuatan hubungannya dengan variabel independen, yaitu dikategorikan menjadi rendah, normal, atau tinggi. RDW berhubungan bermakna kuat dengan klasifikasi diagnosis pneumonia $(x(1)=0,530, p=0,004)$, berhubungan bermakna moderate dengan RISC $\left(r_{s}=0,369, p=0,023\right)$, dan berhubungan bermakna moderate dengan PRESS $\left(r_{s}=0,318, p=0,043\right)$.

Tabel 1 Karakteristik subjek penelitian

\begin{tabular}{|c|c|c|c|c|c|}
\hline Parameter & & Frekuensi & (\%) & Rerata \pm SD (bulan) & Nilai $\mathrm{p}^{*}$ \\
\hline \multirow[t]{2}{*}{ Umur (bulan) } & $2-23$ & 26 & 86,7 & $13,3 \pm 12,2$ & 0,388 \\
\hline & $24-59$ & 4 & 13,3 & & \\
\hline \multirow[t]{2}{*}{ Jenis kelamin } & Laki-laki & 16 & 53,3 & 0,261 & \\
\hline & Perempuan & 14 & 46,7 & & \\
\hline \multirow[t]{2}{*}{ Pematuritas } & Tidak & 22 & 73,3 & 0,520 & \\
\hline & Ya & 8 & 26,7 & & \\
\hline \multirow[t]{2}{*}{ BBLR } & Tidak & 21 & 70,0 & 0,237 & \\
\hline & Ya & 9 & 30,0 & & \\
\hline \multirow[t]{2}{*}{ ASI eksklusif } & Tidak & 16 & 53,3 & 0,261 & \\
\hline & Ya & 14 & 46,7 & & \\
\hline \multirow[t]{2}{*}{ Vaksin campak } & Tidak & 13 & 43,3 & 0,531 & \\
\hline & Ya & 17 & 56,7 & & \\
\hline \multirow[t]{5}{*}{$\mathrm{BB} / \mathrm{U}$} & Severely underweight & 6 & 20,0 & 0,605 & \\
\hline & Underweight & 8 & 26,7 & & \\
\hline & Normal & 13 & 43,3 & & \\
\hline & Overweight & 1 & 3,3 & & \\
\hline & Obesitas & 2 & 6,7 & & \\
\hline \multirow[t]{3}{*}{$\mathrm{TB} / \mathrm{U}$} & Severely stunted & 6 & 20,0 & 0,400 & \\
\hline & Stunted & 3 & 10,0 & & \\
\hline & Normal & 21 & 70,0 & & \\
\hline \multirow[t]{5}{*}{$\mathrm{BB} / \mathrm{TB}$} & Severely wasted & 6 & 20,0 & 0,531 & \\
\hline & Wasted & 7 & 23,3 & & \\
\hline & Normal & 15 & 50,0 & & \\
\hline & Overweight & 0 & 0,0 & & \\
\hline & Obesitas & 2 & 6,7 & & \\
\hline
\end{tabular}

*Hubungan variabel dengan diagnosis pneumonia (uji chi kuadrat) 
Wigit Kristianto dkk: RDW dan MPV sebagai biomarker keparahan pneumonia anak

Tabel 2 Perbandingan nilai RDW dan MPV pada variabel independen

\begin{tabular}{|c|c|c|c|c|}
\hline \multirow{2}{*}{ Parameter } & \multicolumn{2}{|c|}{ RDW } & \multicolumn{2}{|c|}{ MPV } \\
\hline & Rerata \pm SD & $\mathrm{p}$ & Rerata \pm SD & $\mathrm{p}$ \\
\hline \multicolumn{5}{|l|}{ Klasifikasi diagnosis* } \\
\hline Pneumonia & $13,8 \pm 0,94$ & $0,096^{* * *}$ & $4,51 \pm 0,56$ & 0,481 \\
\hline Pneumonia berat & $16,9 \pm 4,36$ & & $8,35 \pm 2,66$ & \\
\hline \multicolumn{5}{|l|}{ RISC ${ }^{* *}$} \\
\hline Rendah & $15,4 \pm 2,55$ & 0558 & $9,22 \pm 2,05$ & 0730 \\
\hline Sedang & $16,1 \pm 4,52$ & 0,378 & $8,9 \pm 1,92$ & $0, / 39$ \\
\hline Tinggi & $18,1 \pm 3,60$ & & $8,1 \pm 2,14$ & \\
\hline \multicolumn{5}{|l|}{ PRESS** } \\
\hline Rendah & 15,3 & $0008 * * *$ & 5,7 & 0200 \\
\hline Sedang & $15,27 \pm 2,17$ & 0,028 & $9,1 \pm 1,91$ & 0,209 \\
\hline Tinggi & $19,8 \pm 6,78$ & & $8,5 \pm 1,62$ & \\
\hline \multicolumn{5}{|l|}{ Respon terapi** } \\
\hline Membaik & $16,1 \pm 4,31$ & 0532 & $9,8 \pm 1,07$ & 0240 \\
\hline Tetap & 13,2 & 0,332 & 6,22 & 0,240 \\
\hline Memburuk & $17,7 \pm 3,33$ & & $8,84 \pm 1,96$ & \\
\hline \multicolumn{5}{|l|}{ Outcome* } \\
\hline Sembuh & $16,0 \pm 4,26$ & 0,370 & $8,7 \pm 1,99$ & 0,300 \\
\hline Meninggal & $17,7 \pm 3,33$ & & $9,8 \pm 1,07$ & \\
\hline
\end{tabular}

*Analisis menggunakan uji t tidak berpasangan

** Analisis menggunakan uji one way ANOVA

*** Perbedaan bermakna $(\mathbf{a}<0,05)$

Tabel 3 Hubungan nilai RDW dan MPV dengan variabel independen

\begin{tabular}{lccccc}
\hline \multirow{2}{*}{ Variabel dependen } & \multicolumn{5}{c}{ Variabel independen } \\
\cline { 2 - 6 } & Diagnosis* & RISC $^{* *}$ & PRESS $^{* *}$ & Respon terapi** $^{* *}$ Outcome $^{*}$ \\
\hline RDW & $0,530^{* * *}$ & $0,367^{* * *}$ & $0,318^{* * *}$ & $-2,250$ & $-0,354$ \\
MPV & 0,071 & $-0,071$ & 0,158 & $-0,059$ & $-0,223$ \\
\hline
\end{tabular}

* Analisis menggunakan uji chi kuadrat

** Analisis menggunakan uji korelasi spearman

*** Perbedaan bermakna $(\alpha<0,05)$

Semua hubungan yang ditunjukkan adalah hubungan positif. Semakin tinggi tingkat RDW maka makin parah diagnosis pneumonia dan semakin besar nilai RISC dan PRESS menunjukkan semakin parah pneumonia yang terjadi.

\section{Pembahasan}

Subjek penelitian ini didominasi oleh kelompok umur 2-23 bulan (86,7\%). Dominasi kelompok yang sama juga terlihat pada penelitian di Instalasi Gawat Darurat
Kota Boston Amerika Serikat dan RSUP H. Adam Malik Medan, meskipun nilainya lebih kecil daripada penelitian ini $(62,5 \%$ dan $57,6 \%) .{ }^{19,20}$ Subjek berumur $<2$ tahun lebih berisiko terkena pneumonia karena sistem imun tubuh belum berkembang sempurna pada beberapa tahun awal kehidupan. ${ }^{21}$ Distribusi jenis kelamin pasien juga hampir sama dengan penelitian sebelumnya yang didominasi oleh jenis kelamin lakilaki. ${ }^{20,22,23}$ Anak laki-laki lebih berisiko terkena infeksi saluran nafas bawah karena respon sel imun T-helper 1 (Th1) diketahui lebih hebat pada anak perempuan. ${ }^{24}$

Faktor risiko pneumonia yang diobservasi, antara 
Wigit Kristianto dkk: RDW dan MPV sebagai biomarker keparahan pneumonia anak

lain, prematuritas, bayi berat lahir rendah (BBLR), air susu ibu (ASI) eksklusif, dan vaksin campak. Pilihan beberapa faktor risiko ini karena faktor risiko utama pneumonia di wilayah Pasifik Barat, antara lain, tidak ASI eksklusif, merokok, polusi udara, malnutrisi, kemiskinan, dan kondisi komorbid seperti prematuritas, berat badan lahir rendah, HIV, serta penyakit jantung kongenital. ${ }^{25}$ Prematuritas dan BBLR terjadi hanya pada sebagian kecil subjek penelitian (26,7\% dan 30\%). Sementara jumlah subjek yang tidak/belum mendapat ASI eksklusif dan tidak/belum vaksinasi campak cukup besar, yaitu 53,3\% dan 43,3\%. Faktor tersebut tidak berhubungan dengan klasifikasi diagnosis pneumonia pada penelitian ini.

Hubungan prematuritas dengan pneumonia masih kontroversial karena ada penelitian yang menyimpulkan terdapat hubungan, tetapi penelitian lain tidak menunjukkan terdapat hubungan. ${ }^{26}$ Berbeda dengan BBLR yang terbukti meningkatkan risiko kejadian pneumonia berat, ${ }^{26}$ maupun kematian akibat pneumonia. ${ }^{27}$ Air susu ibu (ASI) eksklusif yang tidak adekuat juga berhubungan dengan kejadian pneumonia berat ${ }^{26}$ dan kematian karena pneumonia. ${ }^{27}$ Imunisasi yang berhubungan dengan kejadian pneumonia adalah vaksin campak di akhir satu tahun pertama kehidupan karena pneumonia adalah salah satu komplikasi dari penyakit campak. Vaksinasi pneumokokus tidak dinilai sebagai faktor risiko karena vaksin ini tidak rutin diberikan pada anak Indonesia. Terdapat hubungan antara vaksinasi yang belum lengkap dengan kejadian pneumonia berat. ${ }^{26}$ Status nutrisi tidak berhubungan dengan klasifikasi diagnosis pneumonia. Berbeda dengan penelitian sebelumnya yang menyimpulkan terdapat hubungan antara anak berat kurang, perawakan pendek, dan kurus dengan klasifikasi diagnosis pneumonia. ${ }^{26}$

Braun $\mathrm{dkk}^{12}$ meneliti pasien pneumonia dewasa. Hasil penelitian Braun menunjukkan bahwa nilai RDW tinggi ( $>15 \%)$ berhubungan dengan kejadian pneumonia berat yang ditandai dengan length of stay $($ LOS) $>10$ hari, diperlukan perawatan di ICU, dan berhubungan dengan tingginya kematian pada 90 hari setelah kejadian pneumonia. Penelitian lain juga menunjukkan bahwa RDW berhubungan dengan manifestasi penyakit yang lebih parah dan angka mortalitas yang lebih tinggi. ${ }^{12,28}$ Belum banyak penelitian yang mengevaluasi nilai RDW pada pasien pneumonia anak. Satu penelitian pada anak berumur 1-18 tahun di Filipina menyimpulkan bahwa nilai
RDW berhubungan dengan derajat keparahan penyakit maupun risiko kematian pasien dengan pneumonia. ${ }^{29}$ Hasil penelitian tersebut sejalan dengan hasil penelitian ini. Subjek dengan pneumonia berat memiliki nilai RDW yang lebih tinggi daripada subjek dengan pneumonia, dan nilai RDW berhubungan dengan klasifikasi diagnosis dan keparahan penyakit yang diukur menggunakan skor RISC dan PRESS. Semakin besar nilai RDW maka pneumonia yang akan terjadi akan makin berat, dengan skor RISC dan PRESS yang akan makin besar.

Mekanisme yang mendasari hubungan keparahan penyakit dengan nilai RDW masih perlu diteliti lebih lanjut. Hipotesis yang diajukan adalah proses inflamasi dan stres oksidatif yang memengaruhi pembentukan sel darah merah. Hal tersebut dikonfirmasi oleh Lippi $\mathrm{dkk}^{2}$ yang melaporkan nilai RDW berhubungan dengan biomarker inflamasi lain pada subjek umum, dan Semba $\mathrm{dkk}^{30}$ yang melaporkan hubungan RDW dengan kadar antioksidan selenium dan karotenoid pada wanita manula. Inflamasi dan stres oksidatif yang tinggi akan memperburuk manifestasi klinis penyakit dan meningkatkan risiko penyakit yang lebih berat. Penelitian lain menyimpulkan bahwa RDW masih berhubungan dengan peningkatan mortalitas pasien meskipun biomarker inflamasi sudah dikendalikan. Hal ini menunjukkan bahwa proses inflamasi tidak dapat menjelaskan secara menyeluruh hubungan peningkatan nilai RDW dengan peningkatan mortalitas pasien. ${ }^{31}$ Meskipun demikian, peningkatan RDW masih tetap dianggap sebagai sebuah biomarker dari suatu proses inflamasi/disfungsi bone marrowl gangguan eritropoiesis, bukan sebagai sebuah penyebab dari suatu penyakit. ${ }^{32}$

Penelitian sebelumnya telah menunjukkan bahwa nilai RDW berhubungan dengan beberapa sistem skoring untuk menilai prognosis pasien dengan pneumonia. Nilai skor pneumonia severity indeks (PSI) dan skor confusion, urea, respiratory rate, blood pressure, age $\geq 65$ (CURB-65) lebih tinggi pada subjek dewasa yang memiliki nilai RDW tinggi. ${ }^{28} \mathrm{Hal}$ yang sama juga diamati pada skor pediatric index of mortality-2 (PIM-2) pasien anak. ${ }^{32}$ Penggunaan skor PIM-2 pada pasien pneumonia anak memerlukan pemeriksaan laboratorium yang tidak selalu tersedia di fasilitas kesehatan di Indonesia. ${ }^{33}$ Penelitian ini mengevaluasi sistem skoring yang relatif sederhana karena hanya berdasar pada manifestasi klinis yang muncul pada pasien, yaitu skor RISC dan PRESS. 
Wigit Kristianto dkk: RDW dan MPV sebagai biomarker keparahan pneumonia anak

Skor RISC dapat menilai derajat keparahan dan risiko kematian anak dengan pneumonia. ${ }^{16}$ Skor PRESS dapat menilai derajat keparahan pneumonia yang ditunjukkan dalam peningkatan rawat inap pasien, tetapi hubungan skor ini dengan risiko kematian belum dievaluasi. ${ }^{17}$ Penelitian ini adalah penelitian pertama yang mengevaluasi hubungan nilai RDW dengan skor RISC dan PRESS.

Penelitian mengenai nilai MPV pada pasien pneumonia anak juga masih terbatas. Rata-rata nilai MPV pada penelitian sebelumnya diketahui lebih rendah pada pasien dengan pneumonia dibandingkan dengan pasien pneumonia berat maupun pasien normal dengan beda yang bermakna. ${ }^{14}$ Hasil tersebut sama dengan hasil penelitian ini, tetapi tidak didapatkan perbedaan nilai PMV yang bermakna antara pasien pneumonia dan pneumonia berat. Nilai MPV juga tidak berhubungan dengan derajat keparahan diagnosis, skor RISC, skor PRESS, respon terapi, maupun outcome. Penyebab hal ini masih belum diketahui, tetapi diperkirakan hal ini berhubungan dengan respon bone marrow yang masih inadekuat pada fase awal penyakit pneumonia. ${ }^{14}$

Nilai MPV yang lebih tinggi pada pasien pneumonia berat dibandingkan pasien pneumonia diperkirakan terjadi karena pemeriksaan darah lengkap dilakukan pada stadium penyakit yang lebih lanjut. Nilai MPV diperkirakan berkurang selama fase awal pneumonia sehingga nilai MPV akan lebih rendah daripada nilai normal. Nilai MPV kemudian akan meningkat setelah terjadi aktivasi bone marrow meskipun tetap lebih rendah daripada nilai normal. Perbedaan hasil dengan Karadag-Oncel ${ }^{14}$ mungkin disebabkan karena terdapat perbedaan usia dan karakteristik subjek penelitian. Pada penelitian tersebut digunakan subjek berumur 0-18 tahun dan tanpa komorbid penyakit kronis dan anemia.

Keterbatasan penelitian ini, antara lain, sebagian besar subjek juga memiliki penyakit komorbid, sehingga kondisi tersebut dapat memengaruhi manifestasi klinis dan hasil pemeriksaan laboratorium. Pedoman interpretasi hasil laboratorium juga belum menggunakan pedoman nilai referensi lokal, karena jumlah data nilai laboratorium anak sehat masih sangat terbatas di Indonesia. Hal tersebut menyebabkan peneliti tidak dapat membuat kelompok kontrol dalam penelitian ini dan tidak dapat menentukan nilai cut off RDW dan MPV untuk menentukan keparahan penyakit.

\section{Kesimpulan}

Nilai RDW lebih tinggi pada subjek dengan pneumonia berat dibandingkan pasien pneumonia. Nilai RDW juga lebih tinggi pada subjek dengan skor PRESS tinggi daripada PRESS sedang dan rendah. Nilai MPV lebih rendah pada subjek dengan pneumonia daripada pneumonia berat, tetapi perbedaannya tidak bermakna. Nilai RDW berhubungan positif dengan klasifikasi diagnosis pneumonia, dan skor RISC serta PRESS.

\section{Daftar pustaka}

1. Walker CLF, Rudan I, Liu L, Nair N, Theodoratou E, Bhutta ZA, dkk. Global burden of childhood pneumonia and diarrhoea. Lancet 2013;381:1405-16.

2. Lippi G, Targher G, Montagnana M, Salvagno GL, Zoppini G, Guidi GC. Relation between red blood cell distribution width and inflammatory biomarkers in a large cohort of unselected outpatients. Arch Pathol Lab Med 2009;133:628-632.

3. Hu ZD, Chen Y, Zhang L, Sun Y, Huang YL, Wang QQ. Red blood cell distribution width is a potential index to assess the disease activity of systemic lupus erythematosus. Clin Chim Acta 2013;425:202-5.

4. Felker GM, Allen LA, Pocock SJ, dkk. CHARM Investigators. Red cell distribution width as a novel prognostic marker in heart failure: data from the CHARM Program and the Duke Databank. J Am Coll Cardiol 2007;50: 40-47.

5. Tonelli M, Sacks F, Arnold M, Moye L, Davis B, Pfeffer M. For the cholesterol and recurrent events (CARE) trial investigators. Relation between red blood cell distribution width and cardiovascular event rate in people with coronary disease. Circulation 2008;117:163-8.

6. Aktas G, Alcelik A, Tekce BK, Tekelioglu V, Sit M, Savli H. Red cell distribution width and mean platelet volume in patients with irritable bowel syndrome. Przeglad gastroenterologiczny 2014; 9:160-3.

7. Aktas G, Sit M, Dikbas O, Tekce BK, Savli H, Tekce H, dkk. Could red cell distribution width be a marker in hashimoto's thyroiditis? Exp Clin Endocr Diab 2014;122:572-4.

8. Aktas G, Alcelik A, Tekce BK, Savlı H, Uyeturk U, Kurt M dkk. Mean platelet volume and red cell distribution width in hepatosteatosis. Nat J of Med Res 2013;3:264-6.

9. Sit M, Aktas G, Yilmaz EE, Hakyemez IN, Alcelik A, Kucukbayrak A. Platelet parameters in hepatic hydatid cysts. International journal of inflammation 2013; 2013;1-3.

10. Aktas G, Cakiroglu B, Sit M, Uyeturk U, Alcelik A, Savli 
Wigit Kristianto dkk: RDW dan MPV sebagai biomarker keparahan pneumonia anak

$\mathrm{H}$, dkk. Mean platelet volume: a simple indicator of chronic prostatitis. Acta Medica Mediterr 2013;29:551-4.

11. Cakir L, Aktas G, Enginyurt O, Cakir SA. Mean platelet volume increases in type 2 diabetes mellitus independen of Hba1c level. Acta Medica Mediterr 2014;30:425-8.

12. Braun E, Kheir J, Mashiach T, Naffaa M, Azzam ZS. Is elevated Red cell distribution width a prognostic predictor in adult patients with community acquired Pneumonia? BMC Infec Dis 2014;14:129.

13. Golcuk Y, Golcuk B, Bilge A, Irik M, Dikmen O. Combination of mean platelet volume and the CURB-65 score better predicts 28-day mortality in patients with community-acquired pneumonia. Am J Emerg Med 2015; 33:648-52.

14. Karadag-Oncel E, Ozsurekci Y, Kara A, Karahan S, Cengiz $\mathrm{AB}$, Ceyhan M. The value of mean platelet volume in the determination of community acquired pneumonia in children. Ital J Pediatr 2013;8:39-116.

15. World Health Organization (WHO). Integrated Management of Childhood Illness: Chart Booklet. Genewa: WHO; 2014.h.1-2.

16. Reed C, Madhi SA, Klugman KP, Kuwanda L, Ortiz JR, Finelli $\mathrm{L}$, dkk. Development of the respiratory index of severity in children (RISC) score among young children with respiratory infections in south africa. PloS ONE 2012;7:e27793.

17. Miyaji Y, Sugai K, Nozawa A, Kobayashi M, Niwa S, Tsukagoshi H, dkk. Pediatric respiratory severity score (PRESS) for respiratory tract infections in children. Austin Virol Retrovirol 2015;2:1009.

18. Kementerian Kesehatan Republik Indonesia (Kemenkes RI). Pedoman Tatalaksana Pneumonia Balita. Jakarta : Kementerian Kesehatan Republik Indonesia; 2015.

19. Neuman MI, Monuteaux MC, Scully KJ, Bachur RG. Prediction of pneumonia in a pediatric emergency departement. Pediatrics 2011;128:246-53.

20. Dalimunthe W, Daulay RS, Daulay RM. Significant clinical features in pediatric pneumonia. Paediatr Indones 2013;53:3741.

21. NIH National Heart, Lung, and Blood Institute. 2016. Pneumonia. Diakses pada 05 November 2017. Diunduh dari: https://www.nhlbi.nih.gov/health/health-topics/topics/pnulatrisk.
22. Neuman MI, Monuteaux MC, Scully KJ, Bachur RG. Prediction of pneumonia in a pediatric emergency departement. Pediatrics 2011;128:246-53.

23. Hussain SQ, Ashraf M, Wani JG, Ahmed J. Low hemoglobin level a risk factor for acute lower respiratory tract infections (ALRTI) in children. J Clin Diag Res 2014;8:1-3.

24. Muenchhoff M, Goulder PJR. Sex differences in pediatric infectious diseases. JID 2014;209:S120-6.

25. Nguyen TKP, Tran TH, Roberts CL, Fox GJ, Graham SM, Marais BJ. Risk factors for child pneumonia - focus on the western pacific region. Paed Resp Reviews 2017;21:94-101.

26. Jackson S, Mathews KH, Pulanic' D, Falconer R, Rudan I, Campbell H, dkk. Risk factors for severe acute lower respiratory infections in children-a systematic review and meta-analysis. Croat Med J 2013;54:110-21.

27. Sonego M, Pellegrin MC, Becker G, Lazzerini M. Risk factors for mortality from acute lower respiratory infections (ALRI) in children under five years of age in low and middleincome countries: a systematic review and metaanalysis of observational studies. PloS One 2015;10:e0116380.

28. Lee JH, Chung HJ, Kim K, Jo YH, dkk. Red cell distribution width as a prognostic marker in patients with communityacquired pneumonia. Am J Emerg Med 2013;31:72-9.

29. Miranda SJ. Validity of red cell distribution width as a predictor of clinical outcomes in pediatric patients diagnosed with pneumonia. Chest 2017;152:A843.

30. Semba RD, Patel KV, Ferrucci L, dkk. Serum antioxidants and inflammation predict red cell distribution width in older women: the Women's Health and Aging Study I. Clin Nutr 2010;29:600-4.

31. Ku NS, Kim H, Oh HJ, Kim YC, Kim MH, Song JE, dkk. Red Cell distribution width is an independent predictor of mortality in patients with Gram-negative bacteremia. Shock 2012;38:123-7.

32. Ramby AL, Goodman DM, Wald EL, Weiss SL. Red blood cell distribution width as a pragmatic marker for outcome in pediatric critical illness. PLoS ONE 2015;10:e0129258.

33. Shann F, Pearson G, Slater A, Wilkinson K. Paediatric index of mortality (PIM): a mortality prediction model for children in intensive care. Intens Care Med 1997;23:201-7. 